\title{
Service Brand Equity: Cross-Sectional Analysis of Four Service Schemes in Malaysia
}

\author{
Sharizal Hashim and Ernest Cyril deRun
}

\begin{abstract}
It has been noted in the literature, service brand is considered to be one of the most discussed in the service industry. Because service is dominated by experience and credence attributes; therefore an extrinsic cue like brand may help to reduce customers' purchase risk and optimize their cognitive processing abilities towards the service. One of the emerging service brand concepts that used extensively by marketing reseachers is service brand equity. However, there is limited interest looking at the broader application of service brand equity concept across different service categories. This is important to provide service marketers with useful and broader managerial insights in order to establish greater brand managerial sophistication in marketing the services. Hence, the aim of this research is to determine the dimensions of a successful branding strategy of services, to note each specific service sectors requirement, and its differences. The survey method is used in this study. The findings showed that different service category such as health service, retail, hotel and banking in Malaysia posited different dimension of service brand equity. This tends to suggest that, although service brand equity concept provides a significant description of how to brand a service; different services require different approach of branding process. Thus, this may help brand managers to prioritize and allocate which brand equity dimensions is suitable for their service. The principal contribution of the study is that it provides evidence for the validity of service brand equity used in various service contexts.
\end{abstract}

Index Terms - Service brand equity, hotel, health service, retail, banking.

\section{INTRODUCTION}

There are many countries including Malaysia, has taken several steps to liberalize its services sector as the principal engine for their future economic growth. However, liberalization of the service sector is not an easy task due to the issue of credence qualities and intangibility of the service consumption [1]. Thus, the introduction of extrinsic cues such as branding provides creative solution to reduce customers' purchase risk, "tangibilizing the intangible" and optimize their cognitive processing abilities towards service [2]-[4]. One of the emerging service brand concepts that used extensively by marketing researchers is service brand equity. Reference [5] and [6] asserted that service brand equity is important in a service industry. In addition, due to its intangible nature, a service firm that appropriately manages brand equity is more likely to sustain their

Manuscript received December 15, 2012; revised January 23, 2013. This work was supported in part by Malaysia Fundamental Research Grant Scheme 05(10)/653/2007(18).

$\mathrm{S}$. Hashim is with the Faculty of Economics and Business, University Malaysia Sarawak, Malaysia (e-mail: hsharizal@feb.unimas.my).

E. C. deRun is with Centre for Graduate Studies, University Malaysia Sarawak, Malaysia (e-mail: drernest@feb.unimas.my). competitive advantage [7]. Moreover, brand equity allows the top management of service firms to evaluate their brand's positioning relative to their competitors, keep track of the firm's brand equity value and build corrective strategies when necessary [8].

However, one of the various issues faced by today's brand managers is there are limited attention given to investigate the broader application of service brand equity concept across few service categories in the same study [7], [9]. If this is not dealt with, it may have adverse impacts on the branding as well as marketing of the services [10]. Therefore, the objective of this study is to investigate the application of service brand equity across a few service categories in Malaysia as an effort to provide service marketers with useful managerial insights in order to establish greater brand managerial sophistication in marketing services.

\section{LITERATURE REVIEW}

The specific service brand equity concept is based on the cultivation of customer's brand awareness and brand meaning toward a service [4]. The creation of brand awareness is the first step in building brand equity [11], which represents the customers' ability to identify a brand from memory and increase the likelihood of the brand name coming to mind with or without outside aids [12], [13]. On the other hand, brand awareness refers to a customer's knowledge of a brand name and understanding the service category in which the brand competes [14]. Despite its importance, brand awareness is inadequate to build service brand equity. In most situations, customers will consider other aspects such as brand meaning in their brand evaluation process. As the second component of Berry's service brand equity concept, brand meaning is best defined as the customer's perception about a brand that is held in the mind with ideally strong and unique brand associations [4], [15]. Basically, the perception depends on a customer's search attribute information that occurs prior to a purchase and after consumption of the brand [12].

However, the main critique of the service brand equity concepts pertains to the issue of its generalisations. Most studies have described and validated service brand equity using specific service type rather than conduct a comparison study into the various service types. The diversity in the service sector has rendered it difficult to find managerially useful generalizations such as branding to relate to marketing practice [16]. In addition, previous service brand equity model is viewed as more effective in enhancing positive customer hedonics outcomes rather than behavioural changes because the concept explicitly rely on the emotional motives of the consumer buying process [17]. 